\title{
HARVESTING THE UNCOLLECTED FRUITS OF OTHER PEOPLE'S INTELLECTUAL LABOUR
}

\section{Cristian Timmermann ${ }^{1}$}

\begin{abstract}
Intellectual property regimes necessarily create artificial scarcity leading to wastage, both by blocking follow-up research and impeding access to those who are not able to pay the full retail price. After revising the traditional arguments to hinder access to people's intellectual labour, we examine why we should be more open to allow free-riding of inventive efforts, especially in cases where innovators have not secured the widest access to the fruits of their research. We do so by questioning the voluntariness involved in the consumption of objects of innovation, restating the positive social externalities that arise when wider access to the fruits of innovation is facilitated, and examining the eventual harms innovators face.
\end{abstract}

Key words: patents, wastage, free-riding, public domain, benefiting from scientific advancement

\section{Beneficiarse de los frutos inutilizados del trabajo intelectual ajeno}

Resumen: Los regímenes de propiedad intelectual crean necesariamente una escasez artificial que conduce al despilfarro, tanto mediante el bloqueo de investigación derivada y al prohibir el acceso a aquellos que no son capaces de pagar el precio total de venta. Después de analizar los argumentos tradicionales para limitar el acceso al trabajo intelectual ajeno, examinaremos por qué debemos ser más abiertos en permitir el uso gratuito de los esfuerzos inventivos ajenos, especialmente en los casos en que los innovadores no han ofrecido el más amplio acceso a los frutos de sus investigaciones. Para este propósito cuestionaremos la voluntariedad involucrada en el consumo de los objetos de la innovación, mencionaremos las externalidades sociales positivas que surgen cuando se facilita un mayor acceso a los frutos de la innovación, y haremos un examen del tipo de daños que los innovadores eventualmente enfrentan.

Palabras clave: patentes, desperdicio, parasitismo, dominio público, beneficiarse del progreso científico

\section{Colhendo os frutos náo coletados do trabalho intelectual de outras pessoas}

Resumo: Os regimes de propriedade intelectual criam, necessariamente, escassez artificial, levando ao desperdício, tanto por meio do bloqueio de pesquisa de acompanhamento quanto pelo impedimento dreo acesso àqueles que náo são capazes de pagar o preço comercial total. Após rever os argumentos tradicionais para dificultar o acesso ao trabalho intelectual, nós examinamos porque nós devemos ser mais abertos e permitir o parasitismo dos esforços inovadores, especialmente em casos no qual os inovadores náo têm assegurado o acesso mais amplo aos frutos de sua pesquisa. Nós o fazemos por questionar a voluntariedade envolvida no consumo de objetos de inovação, reafirmando as externalidades sociais positivas que surgem quando o acesso mais amplo dos resultados da inovação é facilitado, e examinar a eventuais prejuízos que os inovadores possam enfrentar.

Palavras-chave: patentes, desperdício, parasitismo, domínio público, beneficiando de avanço científico

\footnotetext{
${ }^{1}$ Centro Interdisciplinario de Estudios en Bioética, Instituto de Estudios Internacionales, Universidad de Chile, Chile

Correspondencia: cristian.timmermann@gmail.com
} 


\section{Introduction}

Being able to enjoy the fruits of one's labour is a right that is deeply rooted in the natural law tradition(1). However, when defining exactly how much is entailed in the vague concept of "fruits of one's labour", opinions vary significantly. While some discount vast portions of the value of labour back to society(2), others consider this utterly as theft(3). Most people tend to not follow an extreme position in this regard and place themselves somewhere between these two poles. Thus, we can observe a wide support of both the principle holding that workers are morally entitled to receive at least some benefit from their labour and the principle stating that ownership does not morally entitle to block every single type of unlicensed beneficial usage.

In this article we concentrate our attention on one particular type of work: intellectual labour. We do so for a specific reason, intellectual workers are unable to grasp all (or even the majority of) the opportunities their efforts yield to. Knowledge the produce of the intellectual worker - is a public good, in the sense of being non-rivalrous in consumption(4), therefore leading to virtually endless opportunities to do good or harm. Not even a highly morally conscious inventor with the most efficient sales strategies and research capacities is able to harvest all opportunities her inventions may lead to. It takes a significant amount of effort to survey the opportunities an invention gives rise to and it is prohibitively expensive to identify how much each potential customer is willing to pay for derived products. By nature, intellectual property creates artificial scarcity und thus necessarily wastes opportunities - something highly problematic from an ethical perspective if leading to avoidable suffering and death(5). This problem leads us to the question we dedicate this examination: Do we have a moral right to collect the fruits of the labour an inventor fails to collect? This question is of paramount importance in today's knowledge economy as an affirmative answer could help to justify a moral obligation to opt for sales practices that ensure wider access to the benefits of scientific advancement and so alleviate suffering and improve well-being. Private interests in earning profits from innovation need to be rebalanced with public interests in access to innovation.
We attempt to answer this question by (i) identifying what is there to collect, (ii) examining the natural law arguments supporting exclusivity, (iii) analysing the consequences of Lockean nonwastage provisos applied to intangible goods, (iv) evaluating from an ethical perspective the different forms of free-riding, and finalize by (v) drawing some conclusions for current sales practices.

\section{Uncollected fruits of labour}

As the main incentive system allowing to collect the fruits of innovative efforts policymakers have established a worldwide system of intellectual property protection(6). Temporary exclusivity should give innovators who have made a marketable invention available enough time to recoup reasonable research and development costs as well as gather some profits. By offering temporary exclusivity society incentivizes inventors to disclose their knowledge, instead of relying on trade secrets. After exclusivity expires this knowledge becomes part of the public domain. This trade-off is referred to as the patent bargain(7).

The globalization of intellectual property regimes has made patents the predominant tool used to enable inventors to enjoy the fruits of their labour(8). Briefly stated, the patent system allows inventors to apply for a temporary exclusive right, which following the Trade-related Aspects of Intellectual Property Agreement (1994) lasts 20 years in most jurisdictions (art. 33). Inventions should be novel, allow industrial application and involve an inventive step (non-obviousness) (art. 27.1). Exclusivity also allows recouping significant sales and advertising expenses(9).

Due to their wide use and legal extensiveness, patents have become the most prominent target of criticism when discussing the negative effects of intellectual property regimes - especially in relation to access to patented medicines $(6,10)$. For this reason we will use the example of patents in medicines throughout the paper, as these exemplify the high social costs of the system for society and the need to address systemic injustices(11).

Patents as an innovation incentive tool bring about major justice problems when situated in a world with huge differences in purchasing power 
and research capacity(12). While, as mentioned, it is difficult to collect all apples from an actual tree in one's garden, it is practically impossible to collect all the potential fruits of one's intellectual labour. When being encouraged to sell the fruits of innovation, even the most complex pricing strategy will leave potential customers out. There will be always people who are able or willing to pay more than the cost price, but less then the sales price. The complexity involved is depicted in figure 1, illustrating three different sales practices A, B and C. Each one leads to the same amount of income, but the three leave a decreasing amount of potential users out $(A<B<C)$. In the case the inventor has to collect the fruits of his labour by selling his invention on the market, it will be inevitable that some dead-weights occur, even when choosing complex price-differentiation $s^{2}$. Now, we can imagine that a third party jumps in, identifies this dead-weight as waste and decides to serve those that where previously underserved by offering variants of the inventions that can be marketed or given away more cheaply. A number of potential users may welcome less luxurious variants of objects of innovation.

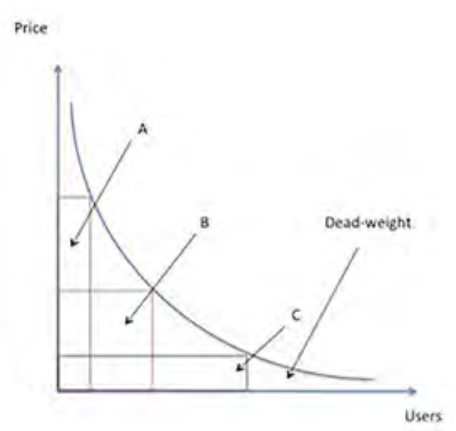

Figure 1

Temporary exclusivity leads also to a second type of underuse of intellectual resources. Many inventions have a potential for secondary usages. The marketed product is often designed to address one of the many possible usages of an invention. Exclusive rights may hinder the possibility to make

\footnotetext{
${ }_{2}^{2}$ Price-differentiation means here charging higher prices to those who have more resources, and to those who have less, lower prices, in order to allow wider access to the objects of innovation and increase revenues.
}

full use of an invention by limiting alternative uses. Particularly open innovation advocates have underlined the importance of allowing and even encouraging user innovation as a key element for scientific and technological progress(13).

I continue my argument by examining if this third party has a right to utilize these unused or underused opportunities, by analysing the traditional justifications for exclusive rights on labour.

\section{Intellectual property, natural rights and argu- ments for denying access to one's labour}

The natural right to enjoy the fruits of one's labour is defended by a number of authors throughout several centuries - the most influential figure being John Locke. The English philosopher famously argued that by mixing labour with a tangible object one could rightfully claim ownership on that object(14: chap. v). Here we should distinguish between the two elements on which ownership is claimed, the fruits of one's labour and the material this labour is mixed with, consisting in an intangible element and a material object. In the case of tangible objects, we cannot detach the labour from the material it is mixed with (i.e. the improvement made on the object). Labour mutates the materials with which it mixes with. By taking this fact in consideration, we can argue that claiming ownership on the object labour is mixed with, underlies practical necessities, as we cannot harvest the fruits of our labour without sufficient access to materials with which our labour was mixed with.

The case of immaterial objects is different(15); we do not mutate the object we mixed labour with - we create a new object, although often with consequences for material and in some cases even immaterial objects. The same practical necessities for allowing ownership do not apply since other methods for harvesting the fruits of intellectual labour are conceivable. As a consequence, the link between owning the object and being able to enjoy the fruits of one's labour is not indispensable. In principle the fruits of intellectual labour can be enjoyed by means other than exclusive ownership (16). Good examples are prize systems that aim at compensating and incentivizing innovation without requiring exclusion from research and 
end products. That such prize schemes, as often suggested for medicines, have not been institutionalized is a failing per se, and not a legitimation for exclusion(17). This argument gains further support, if the objects of innovation are essential to fulfil human rights, such as improved seed varieties for the right to food and medicines for the right to medicines(11). The fact that one's right to enjoy the fruits of one's labour has not been met, does not legitimize to hinder the fulfilment of other people's rights(17). Under this line of reasoning, the human right to benefit from the material interests of one's intellectual work does not lead unconditionally to the often claimed right to own intellectual property, ${ }^{3}$ as a direct causal link is missing. ${ }^{4}$ Intellectual property is neither a sufficient nor a strictly necessary condition for profits.

Yet there might be some hesitations in giving out goods gratuitously. Considering Leo Strauss' widely disputed interpretation of Locke(19), which goes against giving out something for free as it undermines the incentive to mix labour with assets and thus improving them, we still see one easy argument for bringing in an exception for the case of intellectual property in certain fields. The spirit of the Lockean property theory suggests that if people are able to harvest the fruits of their labour, an especial incentive is created to encourage people to do more work and thus enlarge overall welfare. This reasoning vaguely implies that people having assets for free are less prone to work. However, this argument allows room for the idea of unnecessary burden. A certain array of public and private goods has to be available for people to be able to start working more efficiently - as means of production and being productive(20). We recognize this with our idea of having basic needs fulfilled. Inventions can clearly help people to overcome unnecessary burdens. The free distri-

\footnotetext{
${ }^{3}$ Article 27.2 of the Universal Declaration of Human Rights (1948) only secures the protection of "moral and material interests" and therefore does not lead to the recognition of exclusive rights as the sole or necessary vehicle for the fulfilment of these interests. Different is the case of the Charter of Fundamental Rights of the European Union (2000), which mandates the protection of intellectual property (art. 17.2). However, the European Charter does not perceive property rights as absolute and reserves the right to regulate the use of property according to general interests (art. 17.1).

${ }^{4}$ Intellectual property allows only some researchers (those who can cover the necessary expenses) to enjoy the fruits of some of their labour (not all research is patentable and most research is not profitable). Only $1.5 \%$ of patents are ever litigated(18).
}

bution of a vaccine, for example, will not make people less enthusiastic to work and therefore decrease overall welfare. It will rather enable people to undertake productive endeavours they will otherwise not be able to engage in or only pursue inefficiently. Having a healthy body and mind are the central means of production. A similar reasoning applies to labour saving tools that enable individuals to produce efficiently. To take an academic example, there is no social gain in making resource-poorer scholars do a manual literature search when the same documents exist in digitalized and indexed formats. Therefore, a strict prohibition of free-riding - especially when the freeriding comes at no (or little) real or opportunity cost for intellectual property owners - is not in line with the utilitarian ideal of having an incentive to enhance the overall well-being.

We proceed with an examination of the limits of exclusive rights by discussing an application of a Lockean non-wastage proviso to intellectual property.

\section{Applying Lockean non-wastage provisos}

As with the other Lockean provisos, the nonwastage proviso has been subject to widely diverging interpretations and prolonged dispute $(5,21)$. Part of this debate is due to Locke's alternating use of the terms "wasting" and "spoiling" in his chapter on property (14). The subsequent discussion on the introduction of money as a tool to avoid spoilage pushes contemporary interpreters to abandon the non-wastage proviso when applying Locke's reasoning to the modern knowledge economy, and even more, when dealing with intangibles. Yet, in everyday parlance, we frequently say that limiting the accessibility of an object is a waste, even though we are preserving the object from spoilage. Keeping Hieronymus Bosch's "The Garden of Earthly Delights" in a non-illuminated bunker will certainly be a good decision for conservation purposes, but under nearly every other perspective it would definitely be considered as wastage.

Embracing a wider understanding of wastage changes how scholars relate to the non-wastage proviso. For example, a very broad definition of wastage claims that "waste occurs where a unit of a 
product of labour is not put to any use" (22:1182). The same author indicates that waste cannot only occur when potential users are deprived of access, but also when possible uses of intangible units are hindered(22:1189). Others ponder if massive underuse of opportunities may count as wastage as well $(23,24)$. Timely use and availability of an invention can also be called for by a non-wastage proviso(4). Knowledge related to medicines that diminish the negative effects of a disease shows its highest social value when no vaccines for that disease exist.

The imperative of non-wastage would be utterly demanding if we follow such an extensive understanding. Identifying new opportunities and uses comes at a significant cost, as it requires further work, which can be quite extensive. Allowing the manufacture of generic medicines to serve poorer areas requires little extra effort from the inventor, yet finding new uses for already developed drug demands substantial research effort(25). A full examination of additional uses of an idea would require almost endless resources.

Nevertheless, allowing people to benefit from inventive endeavours they have not contributed to still demands an evaluation of the normative nature of free-riding, to which we proceed.

\section{Variations in the concept of free-riding}

Free-riding is generally not perceived as a virtuous act. In today's world the practice of free-riding faces increasingly moral condemnation. A hitchhiker is not anymore someone who is making use of a resource that would otherwise go to waste (e.g. an empty seat during a car ride), but more as someone who does not contribute to the fare. Many online software applications that allow capitalizing on such opportunities have become extremely popular, e.g. by allowing people to sell empty seats on their cars or even nights on an empty sofa. In times of BlaBlaCar and Airbnb we have taken as a society a long distance from the idyllic world of Kerouac's "On the road".

In regard to innovation we often hear the story of the hard working scientist or artist that loses all his potential income by the hand of scrupulous pirates. Ironically, at the same time we can observe another familiar picture, the one of the profit-thirsty corporation that lets everyone perish who is not able to pay for its (life-saving) products. Many ambiguities have to be cleared for an ethical evaluation of the concept of free-riding. Let us review two characterizations of free-riding.

The first characterization of free-riding problematizes the taking of benefits while failing to contribute to the existence of a resource. In this regard, Brian Barry discusses free-riding as "taking the benefits ... while failing to do one's part in sustaining the practice when it is one's turn to do so"(26:229). In a number of social customs reciprocity is expected. In the academic world we would condemn someone who repeatedly shows up at conferences presenting a paper and expecting feedback, but fails to attend any other presentations but her own.

The second characterization emphasizes the problem free-riding raises for the creation of a good. This perspective is illustrated by the definition of free-rider offered by Garrett Cullity(27:5):

"An individual who, in successfully optimizing his own interests, does not contribute to the production of a good that is in joint supply to a certain group, in conditions where it would be collectively self-interestedly suboptimal for the group not to cooperate toward its production".

This definition underlines an essential problem of goods that allow free-riding. A group can significantly improve welfare by pooling resources to construct goods everyone in the group will be able to enjoy. Some goods, particularly public goods, even require a so-called "jointness of production" that involves the pooling of material and intangible resources to come to existence(28). However, people differ in their capacities to contribute to a common pool, be it with time, capabilities, tools or money. We may recall the old socialist saying "from each according to their abilities, to each according to their needs" to gather a picture of the difficulty involved in assessing fair contributions and fair takings(29). While we might be able to identify who contributes and who does not, it is much more difficult and costly to assess who has contributed according to her capacities and who has not. 
Instead of categorically condemning people who are not contributing to the existence of a good despite benefiting from it, we should analyse why people are not doing their share. There are three often-attributed characteristics to free-riding that are crucial to assess when judging the moral nature of such behaviour:

- The consumer is voluntarily consuming the object of innovation.

- The consumer is not willing to pay the price set by the inventor.

- The consumer is harming the inventor by free-riding.

Let us examine these three positions by keeping in mind that we live in a world of extreme inequalities and that many innovations are crucial for subsistence.

\section{Voluntary consumption}

When condemning a person for free-riding, we often assume that the free-rider is voluntarily consuming the object of innovation. From a moral perspective, it is important to differentiate if someone who consumes an object, has the option to choose not to consume it and at what cost this decision comes. As mentioned, the case of access to essential medicines raises the most prominent controversies on patents, in part, because it questions the voluntariness of consumption. Refusing to consume the needed medicines comes at the price of jeopardizing one's health or life. Not offering the medicines to a loved one comes at the price of impeding her chances of healing. Noteworthy is that many medicines relieve pain. In the case of communicable diseases one can avoid being a vector for a disease by taking appropriate medicines.

In a number of cases, by bringing into existence an invention, the inventor changes the background conditions. A world where there is no cure for a disease is a different world than a world where there is a cure but no access. In the former harm is inevitable, in the latter harm is preventable. A society that allows the experience of inevitable harm is different than one that allows the experience of preventable harm. Even in the case where a person has strong moral objections to legitimately acquire a medicine she needs (e.g. because she finds the sales practices of the pharmaceutical company repulsive), she will find it difficult to pretend the drug does not exist and ignore the fact that the manifestation of the disease is something that is preventable. The fear of death or the disease related suffering can have a similar effect than torture in disrupting the person's judgement capacities and thus the possibility of free consent. Refusing the drug is often more than just a difficult choice; it can be outside the boundaries of what one has the freedom to consent(30). In a similar vein, it is different to let someone succumb because death is inevitable or avoidable.

\section{Unwillingness to contribute}

As mentioned, temporary exclusive rights should make it feasible for inventors to recoup reasonable development costs for bringing a saleable product into existence. The practice that is to be sustained is that inventors can expect that their temporary exclusive rights are generally respected so to recoup the investments needed to elaborate their inventions. Also, by having this certainty, inventors can attract investors who are willing to finance the development of their ideas.

There are a number of reasons why consumers might be unwilling to pay the sum requested by the seller of a given invention. Exemplary cases include:

- The consumer is unable to contribute.

- The consumer is willing to contribute to the total costs of production but not to the higher mark-up price.

- The consumer refuses to contribute financially to the rights holder because of moral concerns.

- The consumer is unwilling to contribute due to opportunistic reasons.

Evaluating the reasons why consumers are not contributing to the costs of production is essential to assess the ethical legitimacy of free-riding. Therefore, we will look at these four cases in detail. 
(1) Inability to contribute. People earning less than a dollar a day are obviously unable to pay for essential medicines that cost over 10'000 dollars a year. People should also have enough money left for other essential goods, such as food, after paying for the invention. What good is a drug if one will starve to death while paying for it? We can therefore claim that if after covering all basic needs, a person does not have enough money to pay for the essential invention; she is obviously unable to pay for it. But exactly here we can see the beginning of a grey area. At what stage can we say that basic needs are sufficiently covered to morally oblige someone to pay every remaining cent for a medicine?

A further problem is added when the consumer could contribute through other means, but the inventor fails to offer alternative contribution schemes. A person could offer a variety of bodily services that benefit society as a whole (e.g. offer herself as a human research subject) or serve the inventors' personal interests (with or without losing her dignity). Up to what extent such vulnerabilities can be legitimately exploited, which may include the violation of bodily integrity and losses in dignity, is something that can be democratically established by limiting freedom of contract(31).

(2) The consumer is willing to contribute to the costs of production but not to the higher mark-up price. As we saw earlier, inventors can choose between different sales strategies to recoup their research and development costs. Inventors are generally free to market an invention as a luxury product or as a mass product. If the spirit of the patent bargain is to offer temporary exclusivity for knowledge entering the public domain, people can reasonably object to sales practices that seek to limit the number of consumers who will enjoy the product. Free-riding, as a form of boycotting, gives the public a certain leverage to disincentivize "unfair" sales practices that do not allow the largest number of people to benefit from the advancement of science.

In many cases taxpayers, public scientists and volunteers have contributed to the existence of a product. Inventors often benefit from public grants $(8)$. The complaint that consumers are paying twice, by first contributing with their taxes to facilitate research and then by buying the research product, is often well supported.

Some consumers may consider themselves in a special position. A person may consider fair to spend a certain amount of her income on medicines. Yet in cases where people suffer multiple diseases, they are usually overwhelmingly burdened with medical expenses. Here it is reasonable to claim a reduction of one's overall contributions by arguing that one is already contributing a fair share to sustain the practice of advancing medical innovation by helping innovators recoup their costs. Somewhat more far fetched, but not entirely unsound, is the argument a movies buff or bookworm may put forward in claiming to suffer an expensive taste for diversity over which society should make compromises. Many service providers offer flat rates instead of only pay-per-view options, revealing a certain social acceptance of the fact that people will benefit differently from a particular service despite paying the same. Differential pricing models may therefore even increase the rate consumers judge prices as fair.

\section{(3) The consumer refuses to contribute financially} to the rights holder because of moral concerns. Consumers boycott companies for a wide variety of moral reasons. These reasons are sometimes supported by society at large, in other cases only backed by a small number of concerned citizens or interest groups. We may think of calls to boycott non-essential products from pharmaceutical companies that refused to offer more accessible prices(32). Another example of boycott is the wide distribution of copyrighted articles by academics that morally oppose limitations of access to information.

(4) The consumer is unwilling to contribute due to opportunistic reasons. Under this rubric we can find the stereotypical free-rider who is condemned by many inventors and some of those interested in technological advancement. By giving her share, this free-rider would help innovators recoup research and development costs, which allows innovators to pursue further research. However, the innovator is by no means obliged to reinvest her earnings in future research activities. She could as well cease to put her talent in the service of society and spent her earnings in fashion garments and 
parties. Having done more than her fair share in contributing to social welfare, it would be difficult to reproach such a decision. In practice, many innovators continue to do creative work because they enjoy inventing. As has been repeatedly said, humans are by nature tool-making animals.

\section{Harming by free-riding}

We often hear that inventors would not produce inventions if others are able to copy the invention without compensating the inventor. However, there are countless cases where people innovate - spending resources - without receiving direct benefits and even encouraging others to make use of their inventions. Not only that, we can find new legal tools that allow inventors to share their creative efforts without the fear that these will end up exclusively appropriated. Creative commons licenses are designed to keep innovations in the public domain(33).

Taking a much more optimistic perspective on human nature, James Wilson notes that " $\mathrm{t}]$ he fact that others can $[. .$.$] benefit from their work need$ not provide a disincentive for them, and if they are even moderately altruistic may provide an incentive" (34:455). Foreseeably not having the opportunity to recoup research and development costs cannot in itself qualify as harm. Harm may however occur if the inventors innovates and makes investments based on the legitimate assumption that she will be able to recoup these cost using existing intellectual property regimes. An abrupt change of the rules of the game may indeed cause harm, as innovation often requires long-term investments.

There are a variety of ways free-riders may cause actual or potential harm to inventors. The noncontributing consumer of objects of innovation may cause the following effects:

- Produces no harm.

- Sets a bad example.

- Allows price referencing.

- Deprives the innovator from a potential income possibility.
- Hinders investment when it is rational for all to cooperate.

- Demotivates innovators.

- Let's review these outcomes.

In the first case, where the inventor suffers no harm, we have the situation where the free-rider is not able to contribute and consumes the good without the knowledge of others. By definition, this type of free-rider cannot improve the situation of the inventor since she has no transferable assets to offer as compensation. ${ }^{5}$ Innovations, as understood here, are of non-rivalrous consumption and therefore free-riding does not make the inventor worse off. When the free-rider consumes the product without other people's knowledge she does not produce the effect of providing a "bad example". There are also cases where the free-rider is a member of a special group invited to benefit from the good without contributing to its existence. For example, a number of companies offer access to their objects of innovation through humanitarian licences for Least Developed Countries.

The second case condemns individual free-riding for its likely effect of tempting others to also fail to contribute to the practice of compensating innovators. Laws become increasingly more expensive and difficult to enforce the more people ignore these and the more socially acceptable it is to violate them. A paradigmatic case is corruption(35).

As a third case, we can name price referencing. If the inventor agrees to make some price reductions to the poor, richer customers will gain a better insight of the true cost of production and thus will also demand for price cuts by referring to the price poorer customers are paying. This strategy is often used by countries of the Global North with universal healthcare insurance(36).

The fourth case entails the opportunities lost for financial gain involved in free-rides. In this category, we have to distinguish cases where consum-

\footnotetext{
${ }^{5}$ This is not completely true for the cases of medicines. Markets for medicines without universal health coverage raise a perverse incentive: people who do not have access to drugs can serve as disease vectors. When a disease remains prevalent in an area future demand for medicines, and thus profits, is secured(12).
} 
ers considered paying the sales price of the product and ended up not paying it, and those where consumers are only using the good because they can have free access to it. To exemplify, an early career researcher might plan to buy a particular paperback book but change her mind when she manages to get an illegal copy. In the case she is looking for an article on a particular subject, and the only option to access a candidate article is to pay 40 dollars to get a first glance to see if the article is really useful, she most likely will consult other options that she can more readily access (e.g. an open access repository). It would be derisory to claim that every illicit download amounts to a 40-dollar loss.

The fifth case names instances where research and development activities were terminated or never carried out because of the low possibilities to recoup costs. Here we do not have only cases where patents are ignored, but also cases where research is not patentable. A special case are so-called secondary use indications for medicines, where research shows (or could prove) that existing medicines whose patent has expired can treat other diseases or dysfunctions. The inability to recoup such research costs impedes proving clinical efficacy (25).

The sixth case addresses the problem where an inventive egoists ceases to produce inventions because she disapproves that others benefit from her intellectual labour without adequately remunerating her efforts. To take this case seriously we would have to balance the egoist inventor's interests with the highly altruistic inventor's interests along with society's interests. In the case we face the crude reality that people only make use of their talents when they are able to grasp as much benefits as possible without regard to other people's wellbeing, utilitarian reasoning may demand that we concede the egoists demands, especially for innovations that can address welfare issues.

\section{Concluding remarks}

Let us go back to our original question and examine if we can provide a satisfactory answer. Do we have a moral right to collect the fruits of the labour an inventor fails to collect? An imperative to reduce wastage invites us to answer this question positively. By making use of opportunities the in- ventor fails to exploit, we are reducing wastage of valuable opportunities to reduce harm. However, we also saw that free-riding may jeopardize investment in inventive enterprises and limits the possibilities to enjoy the fruits of one's labour, which may demotivate or even impede some types of innovation. After considering both sides, we will have to settle for a balance of both public and private interests.

In how far free-riding is innovation deterring is ultimately an empirical question to which philosophy has little to say. From a normative perspective we should however note, that the consumer of objects of innovation does in many instances not only satisfies personal needs but also produces a series of social benefits. We mentioned the case of user innovation. People who treat with medicines communicable diseases reduce their propagation(37). Citizens who digested large amounts of information are in a better position to make socially beneficial voting decision. The licit and illicit use of labour saving tools produce a larger output.

Since the innovator does not compensate every single source of inspiration or ideas, it would be unfair to demand that consumers have to fully compensate every single creative effort they absorb. Insisting in a strict market exchange of ideas would increase enormously transaction costs, which undermines higher societal goals such as the improvement of welfare and the maintenance and creation of an innovation-promoting environment.

What implications should we draw from these observations for the unconstrained use of exclusive rights by innovators? Since it is hardly possible for inventors and consumers to compensate every single source of ideas and musings, we should repopularize and re-establish fair use clauses as well as grant wider research exemptions. Further, we need a more active protection of the public domain. Access to information within the public domain should not be hindered to avoid possible infringements of copyright or patents. As a tradeoff, consumers should make a larger effort in providing innovators with quality feedback on their products. It is counterproductive and detrimental for society to insist that every benefit one harvests 
Harvesting the uncollected fruits of other people's intellectual labour - Cristian Timmermann

\section{from other people's creative effort should be com- Acknowledgements:}

pensated.

This research benefited from a post-doctoral fellowship by the DGAPA-UNAM and the LUISS visiting fellowship program.

\section{References}

1. Mossoff A. Saving Locke from Marx: The labor theory of value in intellectual property theory. Social Philosophy and Policy. 2012; 29(2): 283-317.

2. Simon HA. UBI and the Flat Tax. In: Van Parijs P, Cohen J, Rogers J, editors. What's Wrong with a Free Lunch? Boston: Beacon Press; 2001: 34-38.

3. Nozick R. Anarchy, state, and Utopia. New York: Basic Books; 1974.

4. Drahos P. A philosophy of intellectual property. Aldershot: Dartmouth; 1996.

5. Hull G. Clearing the rubbish: Locke, the waste proviso, and the moral justification of intellectual property. Public Affairs Quarterly 2009; 23(1): 67-93.

6. Allard Soto R. El acceso a los medicamentos: conflictos entre derechos de propiedad intelectual y protección de la salud pública. Acta Bioethica 2015; 21(1): 83-91.

7. Liivak O, Peñalver EM. The right not to use in property and patent law. Cornell Law Review 2013; 98: 1437-1493.

8. Stephan PE. How economics shapes science. Cambridge, MA: Harvard University Press; 2012.

9. Páez Moreno R. La investigación de la industria farmacéutica: ¿̨condicionada por los intereses del mercado? Acta Bioethica 2011; 17(2): 237-246.

10. Sterckx S. Patents and access to drugs in developing countries: an ethical analysis. Developing World Bioethics 2004; 4(1): 58-75.

11. Timmermann C. Limiting and facilitating access to innovations in medicine and agriculture: a brief exposition of the ethical arguments. Life Sciences, Society and Policy 2014; 10: 8.

12. Pogge TW. World poverty and human rights. $2^{\text {nd }}$ ed. Cambridge: Polity; 2008.

13. Torrance AW, von Hippel E. The Right to Innovate. Detroit College of Law at Michigan State Law Review 2015; 2:793829.

14. Locke J. Two Treatises of Government. Laslett P, editor. Cambridge: Cambridge University Press; 1689/1960.

15. Hettinger EC. Justifying intellectual property. Philosophy \& Public Affairs 1989; 18(1): 31-52.

16. Cwik B. Labor as the basis for intellectual property rights. Ethical Theory and Moral Practice 2014; 17(4): 681-695.

17. Timmermann C. An assessment of prominent proposals to amend intellectual property regimes using a human rights framework. La Propiedad Inmaterial 2014; 18: 221-253.

18. Lemley MA, Shapiro C. Probabilistic patents. Journal of Economic Perspectives 2005; 19(2): 75-98.

19. Strauss L. On Locke's doctrine of natural right. The Philosophical Review 1952; 61(4): 475-502.

20. Steiner H. The natural right to the means of production. The Philosophical Quarterly 1977; 27(106): 41-49.

21. Widerquist K. Lockean Theories of Property: Justifications for Unilateral Appropiation. Public Reason 2010; 2(1): 3-26.

22. Damstedt BG. Limiting Locke: A natural law justification for the fair use doctrine. The Yale Law Journal 2003; 112: 1179-1221.

23. Sterckx S. The ethics of patenting: uneasy justifications. In: Drahos P, editor. Death of patents. Oxford: Lawtext Publishing; 2005: 175-211.

24. Attas D. Lockean justifications of intellectual property. In: Gosseries A, Marciano A, Strowel A, editors. Intellectual Property and Theories of Justice. Houndmills: Palgrave Macmillan; 2008: 29-56.

25. Syed T. Should a prize system for pharmaceuticals require patent protection for eligibility? IGH Discussion Paper No 2. 2009.

26. Barry B. Humanity and Justice in Global Perspective. Nomos 1982; 24: 219-252.

27. Cullity G. Moral Free Riding. Philosophy \& Public Affairs 1995; 24(1): 3-34.

28. Waldron J. Can Communal Goods Be Human Rights? European Journal of Sociology 1987; 28(2): $296-322$.

29. Gilabert P. The Socialist Principle "From Each According To Their Abilities, To Each According To Their Needs". Journal of Social Philosophy 2015; 46(2): 197-225. 
30. Vossenkuhl W. Die Möglichkeit des Guten. München: C.H. Beck; 2006.

31. Sturn R. Volenti Non Fit Iniuria? Contract Freedom and Labor Market Institutions. Analyse und Kritik 2009; 31(1): 81-99.

32. Hassoun N. Global health impact: a basis for labeling and licensing campaigns? Developing World Bioethics 2012; 12(3): 121-134.

33. Kloppenburg J. Re-purposing the master's tools: the open source seed initiative and the struggle for seed sovereignty. Journal of Peasant Studies 2014; 41(6): 1225-1246.

34. Wilson J. Ontology and the regulation of intellectual property. The Monist 2010; 93(3): 450-463.

35. Garzón Valdés E. Acerca de la calificación moral de la corrupción. Tan sólo una propuesta. Isonomia 2004; 21 : 9-20.

36. Hollis A, Pogge TW. The Health Impact Fund: Making New Medicines Accessible for All. Oslo \& New Haven: Incentives for Global Health; 2008.

37. Selgelid MJ. Ethics and drug resistance. Bioethics 2007; 21(4): 218-229.

Received: May 27, 2016

Accepted: June 7, 2016 